Komang Ayu Suwindiatrini dan Helmi Yanuar Dwi Prasetyo

Balai Pelestarian Cagar Budaya Maluku Utara, Jl. Raya Pertamina, Kel. Jumbula, Kec. Pulau Ternate, Maluku Utara, Indonesia; posel: komang.ayu@kemdikbud.go.id dan helmi.arkeo@gmail.com

Diterima 12 Maret 2021

Direvisi 7 Mei 2021

Disetujui 10 Mei 2021

\section{ARKEOLOGI PUBLIK: PERAN MEDIA BARU DALAM PENYAMPAIAN INFORMASI CAGAR BUDAYA DI MASA PANDEMI}

\author{
PUBLIC ARCHAEOLOGY : THE ROLE OF NEW MEDIA IN \\ DISSEMINATION OF CULTURAL HERITAGE \\ INFORMATION IN PANDEMIC ERA
}

\begin{abstract}
Abstrak. Pandemik Covid-19 di awal tahun 2020 berdampak besar pada seluruh aspek kehidupan manusia. Pembatasan aktivitas banyak diterapkan di berbagai tempat untuk memutus penyebaran virus Corona. Hal tersebut juga berdampak pada kegiatan penyebaran informasi tentang cagar budaya, seperti sosialisasi, pameran, seminar, dan kegiatan lainnya yang tidak bisa dilaksanakan secara tatap muka. Pembatasan aktivitas juga menyebabkan kunjungan museum dan situs-situs bersejarah tidak dapat dilakukan. Pemanfaatan media informasi baru perlu dilakukan untuk menyebarkan informasi tentang cagar budaya secara virtual. Penelitian ini bertujuan untuk menjawab bagaimana peran media baru dalam penyebaran informasi tentang cagar budaya di masa pandemi Covid-19 serta manfaat yang didapatkan oleh masyarakat. Data yang digunakan bersumber internet dan hasil kuesioner yang diikuti oleh responden dari enam belas provinsi di Indonesia dengan menggunakan platform Google Form yang disebarkan melalui sosial media WhatsApp. Hasil penelitian mengetahui bahwa media baru mampu memberikan solusi dalam penyebaran informasi cagar budaya yang biasa dilakukan secara tatap muka dengan menghadirkannya secara virtual. Penyebaran informasi secara virtual juga memberikan ilmu pengetahuan dan pengalaman baru dalam pembelajaran untuk mengenal cagar budaya walaupun dalam kondisi pandemik seperti saat ini.
\end{abstract}

Kata kunci: Cagar Budaya, Pandemi, Covid-19, Media Virtual

\begin{abstract}
The Covid-19 pandemic in early 2020 had a wide impact on all aspects of human life, with activity restrictions aimed at stopping the spread of the Coronavirus. Activity restrictions are widely applied in every place to cut off the transmission of the Coronavirus. The restrictions affect the information dissemination on cultural heritage, such as socialization, exhibitions, seminars, and others that can not be done directly. Due to the restrictions, a site visit to the museum and historical sites is hard to do. The utilization of new media needs to be considered to disseminate cultural heritage information virtually. This study aims to acknowledge the role of new media for information dissemination during the pandemic and its benefits to the community. Data were collected from internet sources and questionnaires followed by respondents using the Google Form platform shared through WhatsApp. The results found out that the new media can provide solutions in cultural heritage dissemination virtually. This new method also provides knowledge and experiences in learning to recognize cultural heritage in this period.
\end{abstract}

Keywords: Heritage, Pandemic, Covid-19, Virtual Media

\section{PENDAHULUAN}

Menyebarluaskan seluruh informasi cagar
budaya merupakan salah satu upaya
memperkenalkan kekayaan tinggalan budaya dan
meningkatkan kesadaran masyarakat akan
pentingnya pelestarian tinggalan budaya di
Indonesia. Undang-undang No. 11 Tahun 2010
tentang Cagar Budaya Pasal 39 menyebutkan
bahwa pemerintah dan pemerintah daerah
melakukan upaya aktif mencatat dan
menyebarluaskan informasi tentang cagar budaya
dengan tetap memperhatikan keamanan dan
kerahasiaan data yang dianggap perlu sesuai
dengan ketentuan peraturan perundang-undangan.
Undang-undang Cagar Budaya menyebutkan

bahwa penyebarluasan informasi cagar budaya dilakukan dengan berbagai cara, antara lain melalui penyuluhan, media cetak, media elektronik, dan pementasan seni. Selain itu, penyebaran informasi tentang cagar budaya juga kerap dilakukan dengan mengadakan pameran-pameran tentang cagar budaya, baik di sekolah, universitas, mal, maupun di ruang publik lainnya (Presiden Republik Indonesia 2010).

Penyampaian informasi cagar budaya kepada masyarakat merupakan bentuk komunikasi antara sejarah masa lampau yang disajikan di masa kini kemudian dapat dijadikan pelajaran untuk masa yang akan datang. Cagar budaya sebagai tinggalan masa lampau memiliki nilai-nilai yang tersimpan di dalamnya dari kejadian-kejadian sejarah, teknologi, 
ilmu pengetahuan, serta kearifan lokal pada masa lalu. Penyampaian informasi cagar budaya merupakan salah satu cara untuk membangkitkan kebanggaan generasi muda akan kejayaan masa lalu bangsa ini (Prasasti 2019). Oleh karenanya, penyampaian informasi cagar budaya yang memiliki nilai-nilai yang terkandung di dalamnya lebih ditujukan kepada generasi muda sebagai generasi penerus bangsa. Mengomunikasikan informasi cagar budaya kepada generasi muda juga diharapkan dapat memperkuat karakter kebangsaan agar dapat memperkokoh persatuan dan kesatuan bangsa Indonesia. Seperti yang dikatakan Yudi Latif dalam tulisan M. Irfan Mahmud (2012): "Kejatuhan politik cuma kehilangan penguasa; kejatuhan ekonomi, cuma kehilangan sesuatu; tetapi kalau kejatuhan karakter, suatu bangsa akan kehilangan segalanya" (Mahmud 2012).

Seiring perkembangan teknologi dan kebutuhan masyarakat luas, penyampaian informasi tentang cagar budaya mengalami pergeseran dari media konvensional ke media digital. Media konvensional yang dimaksud merupakan mediamedia penyampaian informasi cagar budaya seperti poster, pamflet, brosur, papan informasi, buku, sosialisasi, dan sebagainya. Media-media tersebut dianggap sudah tidak sesuai dengan kebutuhan saat ini. Menurut Widodo (2012), penyampaian informasi kepada pihak lain berkaitan dengan permasalahan komunikasi, yaitu proses penyampaian pesan dari suatu pihak ke pihak lainnya. Komunikasi harus memilih sudut yang sesuai dengan kebutuhan publik dengan memilih media yang efektif serta merespon atas informasi yang disampaikan. Media digital kemudian dianggap sebagai media yang lebih sesuai dengan kebutuhan masyarakat saat ini, media berbasis digital inilah yang lazim disebut dengan media baru (Prasasti 2019).

Penyampaian informasi cagar budaya menggunakan media baru memiliki keunggulan karena dapat disampaikan dan diterima oleh masyarakat dengan cepat dan mudah. Media baru yang terhubung dengan internet memungkinkan informasi yang disampaikan dapat diakses di mana saja dan kapan saja. Hanya dengan menggunakan ponsel pintar dan jaringan internet penyampaian informasi mengenai cagar budaya hadir dalam genggaman tangan. Nilai positif yang dimiliki oleh penyebaran informasi melalui internet 62 menjadikannya media yang perlu terus dikembangkan dengan tidak mengurangi nilai penting dari objek aslinya (Amril 2016).

Seiring dengan kecanggihan teknologi saat ini sudah memungkinkan untuk menyampaikan informasi tentang cagar budaya secara virtual dengan menggunakan berbagai media atau aplikasi. Informasi cagar budaya secara virtual memungkinkan penyebaran informasi dan pengenalan cagar budaya tanpa mengenal batasan ruang dan waktu. Menurut Sektiadi (2008), penyajian informasi cagar budaya secara virtual dapat digunakan sebagai upaya konservasi karena dapat menggantikan objek asli dan mengurangi dampak kerusakan objek asli mengingat benda arkeologi atau koleksi museum memiliki karakter yang rapuh dan tidak dapat diperbaharui. Beberapa penelitian telah menghasilkan aspek-aspek penting untuk merancang cagar budaya virtual yang memfasilitasi pembelajaran budaya (Revianur 2020). Dengan demikian penyampaian informasi cagar budaya akan makin menarik dan interaktif sehingga lebih mudah diterima di masyarakat.

Dengan adanya pandemi Covid-19, penyebaran informasi secara konvensional sangat tidak memungkinkan. Penyebaran informasi seperti sosialisasi, penyuluhan, pameran atau kegiatan lain dengan menghadirkan banyak orang tidak bisa dilakukan sama sekali. Pembatasan aktivitas dan ruang gerak dilakukan di segala sektor, anjuran pemerintah untuk tetap di rumah menambah sulitnya menyebarkan informasi cagar budaya di ruang umum. Di sinilah media baru berperan penting dalam penyebaran informasi cagar budaya. Informasi cagar budaya di dunia nyata kemudian dibawa ke dalam dunia maya yang dapat diakses oleh masyarakat di mana saja dan kapan tanpa harus mengunjungi museum, situs-situs bersejarah atau kegiatan di luar rumah yang memungkinkan terjadinya penyebaran Virus Corona.

Tulisan ini merupakan desk research, oleh karenanya data yang dikumpulkan atau dijaring secara virtual, termasuk dalam penyampaian kuesioner kepada responden dilakukan secara digital. Tulisan ini bertujuan untuk mengulas peran media baru dapat menjembatani keterbatasan dalam penyebaran informasi tentang cagar budaya pada masa pandemi, selain itu melihat bagaimana media baru dapat memberikan manfaat kepada masyarakat dalam mengakses informasi tentang cagar budaya di masa pandemi saat ini. 
Pembahasan mengenai media baru di masa pandemi memang telah banyak diulas, namun kaitannya dengan penyebaran informasi tentang cagar budaya belum pernah dibahas sebelumnya. Oleh karenanya, hasil dari tulisan ini diharapkan dapat mengetahui sejauh mana peran media baru dalam upaya penyampaian informasi tentang cagar budaya khususnya di masa pandemi serta mengetahui manfaat yang dirasakan oleh masyarakat dengan segala kekurangannya.

\section{METODE}

Metode yang digunakan adalah penelitian kuantitatif. Metode penelitian kuantitatif yaitu salah satu jenis penelitian yang mendetail pada sistem, rencana dan struktur yang jelas dari permulaan hingga pengerjaan desain penelitiannya. Pengertian lain menyebutkan jika penelitian kuantitatif merupakan penelitian yang sering menggunakan angka, mulai dari pengumpulan data, interpretasi hingga penampilan hasilnya. Pada tahap kesimpulan penelitian, keberadaan gambar, tabel, grafik, maupun sajian data lainnya yang menyertai akan menjadi lebih baik (Siyoto dan Sodik 2015). Statistik deskriptif adalah statistik yang digunakan untuk menganalisis data dengan cara mendeskripsikan atau menggambarkan data yang sudah terhimpun sebagaimana adanya tanpa ada tujuan untuk menyimpulkan yang berlaku untuk umum atau generalisasi (Siyoto dan Sodik 2015).

Berdasarkan survei yang telah dilakukan dengan menggunakan kuesioner melalui platform Google Form, sebanyak 106 responden telah menjawab sepuluh pertanyaan yang diajukan. Kuesioner yang disebarkan dari tanggal 15-23 Februari 2021 ini diisi oleh 106 responden, yaitu 50 orang wanita dan 56 orang pria dari berbagai wilayah di Indonesia. Responden berasal dari berbagai wilayah di Indonesia, yaitu Sumatra Barat, Kepulauan Riau, Lampung, DKI Jakarta, Banten, Jawa Barat, Jawa Tengah, D.I. Yogyakarta, Jawa Timur, Bali, NTB, Kalimantan Utara, Kalimantan Selatan, Kalimantan Timur, Sulawesi Selatan, dan Maluku Utara. Rentang usia responden antara 1962 tahun dengan berbagai macam profesi dari mahasiswa, ASN, tenaga pengajar, pekerja lepas, peneliti, dan fotografer. Penyebaran dilakukan dengan cara menyebarkan tautan kuesioner dari satu grup WhatsApp ke grup lainnya.

Penulis mendeskripsikan data sampel yang diperoleh dari kuesioner yang telah disebarkan tanpa membuat kesimpulan untuk menggambarkan populasi dari sampel yang diambil, maka digunakan statistik deskriptif. Hasil sajian data dapat dilakukan dengan mencari frekuensi mutlak, frekuensi relatif (persentase), serta mencari ukuran tendensi sentralnya berupa modus, median, dan mean (Arikunto dalam Siyoto dan Sodik 2015). Fungsi dari statistik deskriptif ini adalah untuk mengelompokkan suatu data variabel dari kelompoknya masingmasing, dari sesuatu yang belum teratur menjadi data yang mudah dicerna oleh orang yang membutuhkan informasi tersebut.

\section{HASIL DAN PEMBAHASAN}

\section{Pandemi Covid-19}

Coronavirus Disease 19 atau Covid-19 masuk di Indonesia sejak bulan Maret tahun 2020, sejak saat itu Indonesia kemudian melakukan pembatasan aktivitas masyarakat yang disebut dengan PSBB, Pembatasan Sosial Berskala Besar. Selain itu, juga menerapkan protokol kesehatan dengan melakukan 3M (Mencuci tangan, Memakai masker, dan Menjaga jarak) menjadi kewajiban selama masa pandemi ini. Kebijakan ini merupakan langkah yang diambil oleh pemerintah untuk menanggulangi penyebaran Virus Corona di Indonesia. Pembatasan pergerakan manusia mengikuti anjuran dari WHO sebagai otoritas kesehatan dunia dengan menerapkan social distancing, atau menjaga jarak sosial dengan kata lain mengurangi kontak dan menjauhi kerumunan dengan orang lain. Hal tersebut mengakibatkan terbatasnya interaksi sosial antarmanusia untuk sementara yang juga berimbas pada seluruh aktivitas masyarakat Indonesia secara umum. Anjuran pemerintah untuk tetap di rumah juga diserukan untuk menekan penularan virus ini.

Adanya pandemi Covid-19 ini, seluruh kegiatan, baik kegiatan agama, ekonomi, pariwisata, kebudayaan, maupun pendidikan mengalami pembatasan dan bahkan untuk beberapa kegiatan ditiadakan, dan diliburkan. Sesuai dengan Peraturan Pemerintah Nomor 21 Tahun 2020 tentang Pembatasan Sosial Berskala Besar dalam Rangka Percepatan Penanganan Corona Virus Disease 2019 (Covid-19), pada pasal 4 menyebutkan bahwa PSBB paling sedikit meliputi peliburan sekolah dan tempat kerja, pembatasan kegiatan keagamaan, dan/atau pembatasan kegiatan di tempat atau fasilitas umum. 
Kementerian Pendidikan dan Kebudayaan melalui Surat Edaran 4 Tahun 2020 tentang Pelaksanaan Kebijakan Pendidikan dalam Masa Darurat Penyebaran Corona Virus Disease (Covid-19) menetapkan pembelajaran siswa dilaksanakan dari rumah dengan ketentuan sebagai berikut: a). Belajar dari Rumah melalui pembelajaran daring/jarak jauh dilaksanakan untuk memberikan pengalaman belajar yang bermakna bagi siswa, tanpa terbebani tuntutan menuntaskan seluruh capaian kurikulum untuk kenaikan kelas maupun kelulusan; b). Belajar dari Rumah dapat difokuskan pada pendidikan kecakapan hidup antara lain mengenai pandemi Covid-19; c). Aktivitas dan tugas pembelajaran Belajar dari Rumah dapat bervariasi antarsiswa, sesuai minat dan kondisi masingmasing, termasuk mempertimbangkan kesenjangan akses/fasilitas belajar di rumah; d). Bukti atau produk aktivitas Belajar dari Rumah diberi umpan balik yang bersifat kualitatif dan berguna bagi guru, tanpa diharuskan memberi skor/nilai kuantitatif (Menteri Pendidikan dan Kebudayaan Republik Indonesia 2020; Presiden Republik Indonesia 2020)

Selama pandemi Covid-19 memang kondisi di Indonesia bahkan di seluruh dunia belum bisa dipastikan, walaupun sudah ditemukan vaksin namun belum bisa $100 \%$ menghilangkan virus yang juga disebut SARS Cov-2 ini. Oleh karenanya, kondisi seperti ini belum bisa dipastikan akan berakhir kapan. Di Indonesia sendiri, angka kasus terpapar virus ini justru makin meningkat. Menurut situs resmi Satgas Penanggulangan Covid-19 per tanggal 16 Februari 2021, penyebaran Virus Corona masih mengalami peningkatan dan belum ada tanda-tanda terjadinya penurunan, dengan demikian belum ada jaminan kapan pandemi ini akan berakhir (Gambar 1).
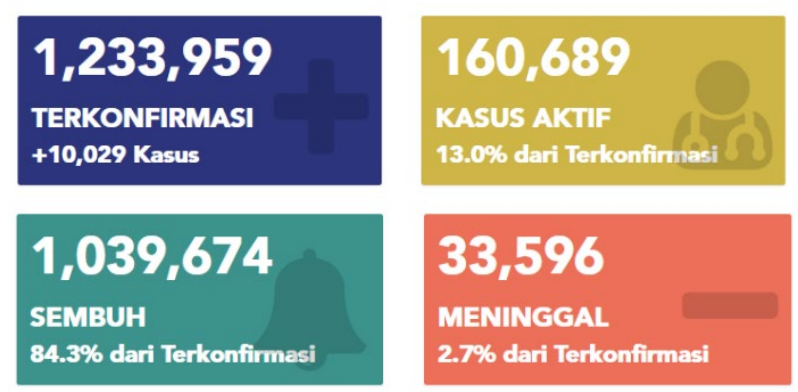

Sumber: https://covid19.go.id/peta-sebaran-covid19 (Diakses pada tanggal 16 Februari 2021)

Gambar 1 Angka kasus Virus Corona di Indonesia

Kaitannya dengan penyebaran informasi cagar budaya di masa pandemi ini, selama virus ini 64 masih ada dan penyebarannya belum bisa dihentikan maka penyebaran informasi tentang cagar budaya tidak bisa mengandalkan kegiatan yang menyebabkan kerumunan yang justru berpotensi meningkatkan penyebaran Virus Corona. Lokasi-lokasi informasi cagar budaya seperti situssitus bersejarah dan museum juga terpaksa ditutup sementara, kalaupun bisa dikunjungi ada aturan yang membatasi jumlah pengunjung dan menerapkan protokol kesehatan secara ketat, termasuk mengukur suhu tubuh setiap pengunjung. Kondisi seperti ini memang menuntut beberapa pihak yang memiliki kewajiban dalam menyampaikan informasi tentang cagar budaya melakukan penyampaian informasi dengan menggunakan berbagai media elektronik. Tentunya karena tidak bisa melihat langsung benda-benda bersejarah dan berinteraksi langsung di lokasi, penyampaian informasi tentang cagar budaya dilakukan secara menarik, kreatif dan interaktif. Menurut Numatias (2018), manfaat media informasi sebagai aplikasi multimedia antara lain: 1). Proses pembelajaran lebih menarik, lebih interaktif, lebih efektif, dan mudah dijangkau; 2). Memperkecil benda besar yang tidak bisa dihadirkan di suatu tempat; 3). Menyajikan benda atau peristiwa yang terjadi di masa lalu dan/atau di lokasi yang jauh; 4). Menyajikan peristiwa yang kompleks, rumit dan berlangsung lama.

Dengan adanya pandemi Covid-19, penyebaran informasi tentang cagar budaya tidak bisa berhenti begitu saja karena penyebaran informasi tentang cagar budaya merupakan upaya untuk meningkatkan pengetahuan masyarakat tentang nilai-nilai kebangsaan dan menguatkan karakter bangsa. Oleh karenanya, meski dengan kondisi yang penuh dengan keterbatasan, penyebaran informasi tentang cagar budaya kepada masyarakat dan generasi muda harus tetap berlangsung dengan memanfaatkan teknologi dan media baru.

\section{Penyampaian Informasi Cagar Budaya Secara Virtual}

Secara institusional, lembaga yang memiliki wewenang dalam bidang kebudayaan, salah satunya adalah Direktorat Jenderal Kebudayaan, Kementerian Pendidikan dan Kebudayaan. Direktorat Jenderal Kebudayaan bertugas menyelenggarakan perumusan dan pelaksanaan 
kebijakan di bidang kebudayaan, seperti kesenian, tradisi, sejarah, cagar budaya, permuseuman, dan warisan budaya. Visi Bidang Kebudayaan: "Terbentuknya Insan dan Ekosistem Kebudayaan yang Berkarakter dengan Berlandaskan Gotong Royong" (Sekretariat Direktorat Jenderal 2016).

Misi:

1. Mewujudkan insan budaya yang kuat, tangguh dan berkarakter.

2. Mewujudkan pelestarian nilai sejarah dan warisan budaya yang berkelanjutan.

3. Mewujudkan inovasi dan kreativitas karya budaya yang berdaya saing.

4. Mewujudkan diplomasi budaya yang efektif dan produktif.

5. Mewujudkan penguatan tata kelola serta peningkatan efektivitas birokrasi dan pelibatan publik.

Tujuan Pembangunan Bidang Kebudayaan:

1. Peningkatan kapasitas dan peran insan budaya dalam melestarikan kebudayaan.

2. Peningkatan pelestarian warisan budaya (benda dan tak benda).

3. Peningkatan daya saing karya budaya yang efektif dan produktif.

4. Peningkatan diplomasi budaya yang efektif dan produktif.

5. Peningkatan sistem tata kelola yang transparan dan akuntabel dengan melibatkan publik.

Dikaitkan dengan pandemi Covid-19, selaras dengan tugas Direktorat Jenderal Kebudayaan, maka semestinya pandemi bukanlah sebuah halangan. Keterbatasan tatap muka harus dijadikan sebagai momentum untuk tetap mewujudkan inovasi dan kreativitas. Apalagi dalam ekosistem kebudayaan, media baru menjadi salah satu dasarnya. Sehingga menjadi kewajaran jika Direktorat Jenderal Kebudayaan dan UPT (Unit Pelaksana Teknis) yang tersebar di seluruh Indonesia untuk tetap dapat menginformasikan dan mengedukasi tentang cagar budaya. Jalinan apik antara teknologi dan keterbatasan yang berlangsung dalam waktu yang tidak diketahui berakhir hingga kapan, mendorong berbagai kegiatan atau acara yang berbasis media baru. Media baru seperti yang dipaparkan oleh Denis McQuail dalam Teori Komunikasi Massa (Nugroho 2020), media baru adalah wadah dimana semua pesan komunikasi bisa terpusat dan mudah untuk disalurkan menggunakan teknologi internet dan melibatkan audiens untuk meningkatkan proses interaksi dan komunikasi.

Pada dasarnya, media baru adalah produk dari budaya dunia maya dengan teknologi komputer modern. Tidak heran jika media baru akan selalu berkembang setiap waktunya. Seperti yang terjadi saat ini, informasi dapat tersebar dan diakses di mana saja dan kapan saja. Beberapa ciri khas kemunculan media baru adalah digitalisasi, konvergensi, interaktivitas, virtuality dan hypertextuality (Nugroho 2020). Digitalisasi adalah media baru yang keseluruhannya berbentuk digital. Konvergensi adalah penyatuan berbagai macam komunikasi seperti komunikasi massa cetak, televisi, radio, internet bersama dengan teknologi portable melalui berbagai platform media digital. Interaktivitas merupakan proses komunikasi antara pengguna dengan berbagai platform media yang kini tersedia. Virtuality sendiri berarti menghadirkan objek secara langsung dalam platform yang telah diakses secara virtual. Yang terakhir namun tidak kalah penting, yaitu hypertextuality yang menjadi nadi dari dokumen internet yang dibuat dengan bahasa markup hypertext sederhana (HTML). Sehingga mendorong ciri bahwa media baru pasti akan menggunakan hyperlink internal dan eksternal serta informasinya berpindah dari satu perangkat ke perangkat lainnya.

Cagar budaya masih belum begitu banyak dikenal oleh masyarakat luas, dirasa masih menjadi milik beberapa kalangan tertentu saja. Padahal cagar budaya adalah sesuatu yang penting dan harus diketahui keberadaannya, untuk dilestarikan bersama. Untuk menarik atensi khalayak, penggunaan media baru telah diterapkan oleh Direktorat Jenderal Kebudayaan dan UPT di bawahnya. Memang tidak mudah untuk membiasakan penyelenggaraan kegiatan, apalagi skala besar dan "memindahkan" kegiatan langsung ke sebuah kegiatan daring. Namun sepertinya setelah menjadi kebiasaan, tentunya dapat dilihat penyelenggaraan kegiatan berbasis teknologi seperti ini ternyata lebih efisien.

Salah satu program yang digagas oleh Direktorat Jenderal Kebudayaan adalah Kemah Budaya Kaum Muda (KBKM) (Gambar 2). Jika sebelum pandemi Covid-19 melanda, kegiatan ini diselenggarakan secara luring. Sedangkan KBKM 2020 diselenggarakan secara daring. Walaupun kompetisi tahun 2020 dikurangi daripada tahun 
sebelumnya, tapi dijelaskan dalam katalog KBKM 2020 bahwa kegiatan ini justru menuntut fokus sedari awal. KBKM menjadi platform kerja budaya guna menjawab tantangan pemajuan kebudayaan termasuk di dalamnya juga Cagar Budaya, dengan memanfaatkan kemampuan di bidang STEAM (Science, Technology, Engineering, Arts and Mathematics) dalam Revolusi Industri 4.0.

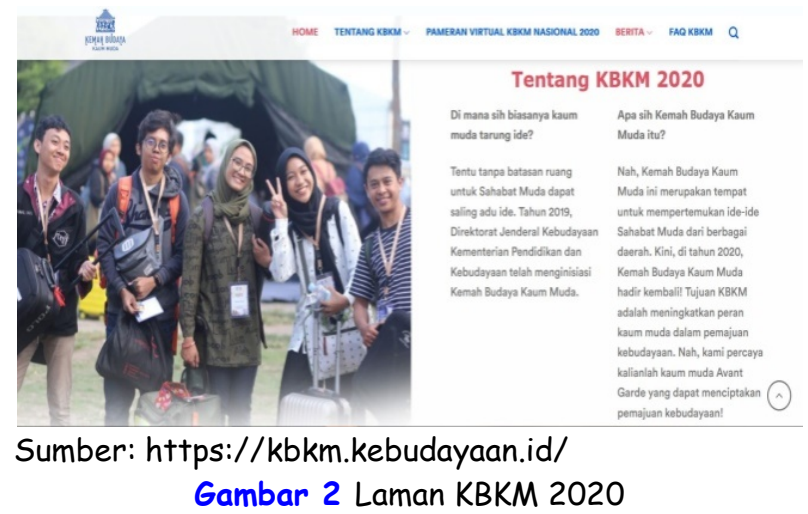

Pola Kegiatan KBKM 2020 dengan promosi yang gencar memanfaatkan berbagai media sosial dari awal hingga akhir. Berbagai webinar, forum tanya jawab melalui kanal YouTube dan siaran langsung instagram. Bahkan sms berantai dan email blast juga disebarkan kepada masyarakat. Dengan hasil di luar dugaan ternyata 717 kelompok atau 3450 orang terdaftar sebagai peserta. Salah satu kegiatan nasional lainnya yang menarik perhatian adalah Pekan Kebudayaan Nasional (PKN) 2020. Lagi-lagi, kreativitas tidak terhalang keterbatasan.

Seperti yang dilansir dalam laman resmi Direktorat Jenderal Kebudayaan, bahwa PKN 2020 tetap digelar walaupun negara sedang dilanda pandemi Covid-19. Sebagai pijakan dasar dalam menghadapi pandemi, PKN kali ini mengambil tema Cultural Resilience. Dengan empat program dasar, yaitu Kompetisi, Pergelaran, dan Konferensi yang dapat disaksikan daring. Khusus untuk pameran, ada dua pameran yang dapat disaksikan langsung di Galeri Nasional dan Museum Nasional Jakarta. Hingga tulisan ini disusun, untuk acara pembukaan PKN yang ditayangkan di kanal YouTube Direktorat Jenderal Kebudayaan sudah ditonton hampir 23.000 kali (Gambar 3).

Belum lama ini, Direktorat Jenderal Kebudayaan mengeluarkan program lainnya, yaitu Fasilitasi Bidang Kebudayaan. Informasi lengkapnya dapat dilihat di https://fbk.id/. Dalam petunjuk teknis, telah dijabarkan bahwa untuk mewujudkan terbentuknya kerja bersama dalam memajukan kebudayaan, Presiden Republik Indonesia mencanangkan dana abadi kebudayaan yang dapat diakses mulai tahun 2022. Fasilitasi Kebudayaan ini menstimulus dan mengawal dana abadi tersebut serta menjaga ritme dinamika pemajuan kebudayaan di masyarakat.

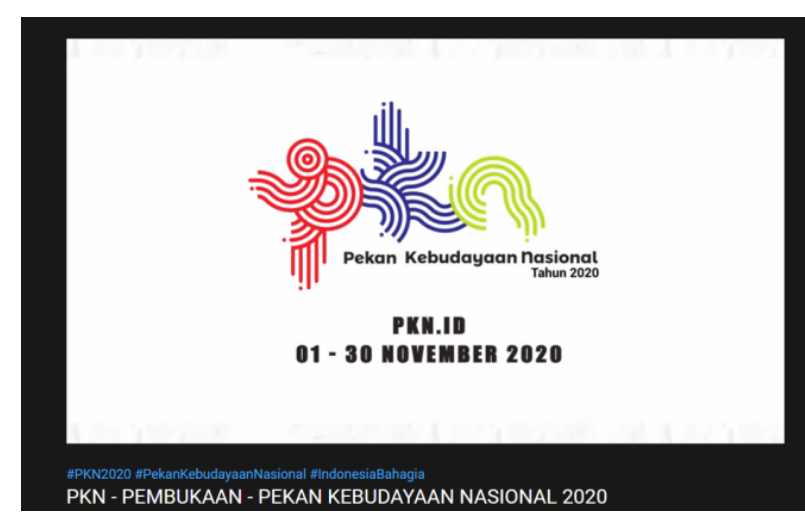

Sumber: https://www.youtube.com/

Gambar 3 Pembukaan PKN di Kanal Youtube

Dengan situasi Covid-19 ini yang juga memberikan dampak bagi bidang kebudayaan, dapat mulai diatasi dengan pemberlakuan perilaku kenormalan baru dan tetap menjalankan protokol kesehatan. Demi menjaga semangat dan terjaganya penyaluran ekspresi dan kreativitas pelaku budaya, maka diupayakan pemberian fasilitasi dalam mendanai berbagai kegiatan kebudayaan.

Bantuan pemerintah berbentuk dana ini diberikan kepada perseorangan, komunitas budaya, dan organisasi/lembaga masyarakat yang berkecimpung dalam bidang kebudayaan. Fasilitasi tahun ini memiliki tema "Ketahanan Budaya". Bantuan ini dibagi dalam tiga tahapan, yaitu persiapan, seleksi, dan pelaksanaan kegiatan bantuan. Untuk tahap persiapan, murni disiapkan oleh tim internal, sedangkan untuk peserta yang ingin berpartisipasi di tahap pendaftaran, sudah sangat dimudahkan karena hanya perlu mengisi boring di laman https://fbk.id saja.

Jika lolos seleksi kelayakan substansi, peserta mengunggah dokumen persyaratan administrasi dan teknis. Jadi, bagi siapa saja yang memiliki ide untuk berpartisipasi dalam fasilitasi kebudayaan terkait ketahanan budaya, dapat mengunggah dari lokasi masing-masing dan menanti pengumumannya yang dibagikan di berbagai media 
sosial resmi milik Direktorat Jenderal Kebudayaan. Segala informasi telah diunggah lengkap di laman tersebut, bahkan masyarakat yang ingin menyampaikan pertanyaan, keluhan dan lainnya dapat memanfaatkan fitur chat yang langsung diarahkan ke WhatsApp.

Selain Direktorat Jenderal Kebudayaan, ada beberapa UPT yang tersebar di berbagai wilayah di Indonesia yang juga memiliki tanggungjawab di bidang kebudayaan. Dalam tulisan ini akan ada upaya-upaya penyebaran informasi tentang cagar budaya daring dari Balai Pelestarian Cagar Budaya (BPCB) Sumatra Barat, BPCB Jambi, BPCB D.I. Yogyakarta, Direktorat Perfilman, Musik dan Media Baru, Museum Nasional, dan BPCB Sulawesi Selatan.

Seperti kebersamaan dari masa lalu warisan Kerajaan Dharmasraya yang tergurat seiring aliran Sungai Batanghari yang menyimpan jejak kejayaannya yang diungkap melalui Pameran Virtual dengan tema "Menjaga Warisan Klasik Dharmasraya". Pameran ini disiarkan langsung di kanal YouTube BPCB_Sumbar. Bahkan, untuk menarik minat masyarakat, ada hadiah uang tunai, sertifikat, dan voucher pulsa.

Sebuah terobosan juga telah diselenggarakan BPCB Jambi, yaitu mengadakan Lomba Pembuatan Konten Digital Bahan Ajar Muatan Lokal Tema Cagar Budaya dan Nilai Sejarah untuk Guru SMP dan SMA se-Provinsi Jambi. BPCB Jambi bekerjasama dengan LPMP dan Kantor Bahasa Provinsi Jambi serta Pemerintah Provinsi Jambi. Melalui poster yang telah diunggah, ada salah satu rangkaian yang digelar menggunakan aplikasi Zoom yaitu taklimat lomba. Bahkan disiapkan hadiah bagi para guru yang aktif.

Adanya pandemi membuat Jelajah Budaya yang biasanya dilakukan dengan penelusuran langsung, kini dialihkan menjadi virtual. Mengusung tema "Cagar Budaya: Eksistensi, Nilai Penting dan Pelestariannya untuk Memperkuat Kepribadian Bangsa", yang diselenggarakan dengan peserta berasal dari komunitas pelestari cagar budaya, anggota pramuka dari Kwartir Daerah Gerakan Pramuka, dan juga paguyuban duta di D.I. Yogyakarta (Gambar 4). Melalui aplikasi Zoom, dijelaskan secara rinci mengenai Candi Prambanan, Candi Banyunibo, dan Candi Kedulan. Jika dahulu Jelajah cagar budaya dilakukan dengan datang ke situs, ternyata pengalihan ke cara virtual tidak mengurangi makna dan upaya BPCB D.I. Yogyakarta untuk memberikan pemahaman dan wawasan kepada generasi muda tentang pelestarian cagar budaya.

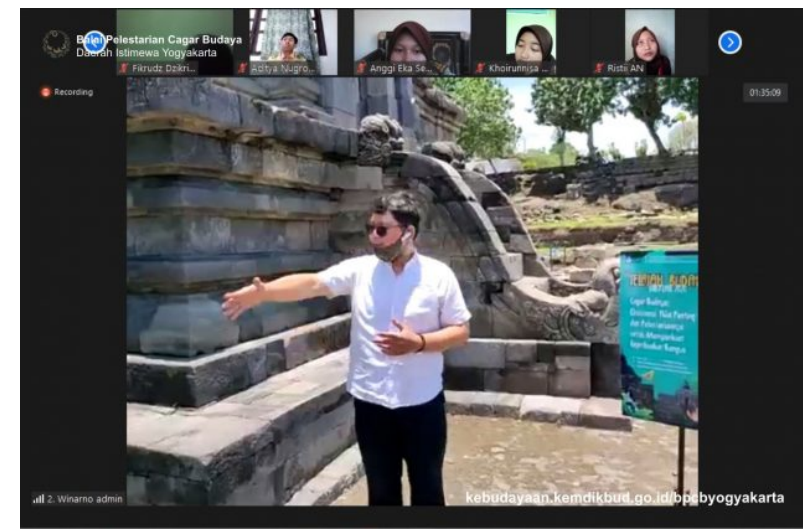

Sumber:http://kebudayaan.kemdikbud.go.id/ bpcbyogyakarta/menjelajahi-candi-via-daring/

Gambar 4 Salah seorang arkeolog yang memberikan materi tentang Candi Kedulan

Konser Rapsodia Nusantara adalah program besutan Direktorat Perfilman, Musik dan Media Baru yang ditayangkan di Kanal Budaya Saya milik Direktorat Jenderal Kebudayaan (Gambar 5). Perjalanan indah berkunjung ke candi-candi mengajak penonton hanyut dalam karya Ananda Sukarlan dan kolaborasi dengan musisi dan penyanyi pendukungnya yang memesona dengan latar yang megah dan bersejarah. Rapsodia Nusantara merupakan gaya, versi, dan interpretasi alunan piano dalam melodi lagu rakyat nusantara. Dijelaskan dalam kanal Budaya Saya jika acara ini dibuat untuk memantapkan identitas musik klasik Indonesia dan mewujudkan potensinya dalam pendidikan, sejarah, dan juga nilai artistiknya.

Lain halnya dengan keseruan yang ditampilkan oleh Museum Nasional. Museum Nasional mengadakan Cerdas Cermat Museum (LCCM) yang berasal dari perwakilan siswa-siswi SMP/MTs dari seluruh provinsi di Indonesia (Gambar 6). LCCM ini dilaksanakan secara daring karena pandemi Covid-19. Walaupun ada kekhawatiran terkait masalah jaringan namun koordinasi dan penggunaan aplikasi telah dipastikan berulang kali untuk memastikan kesiapan. Mengusung tema "Generasi Cerdas Berkarakter", diselenggarakan dalam dua tahapan, yaitu penyisihan dan final. Kompetisi ini disiarkan secara langsung di kanal YouTube Museum Nasional Indonesia. 


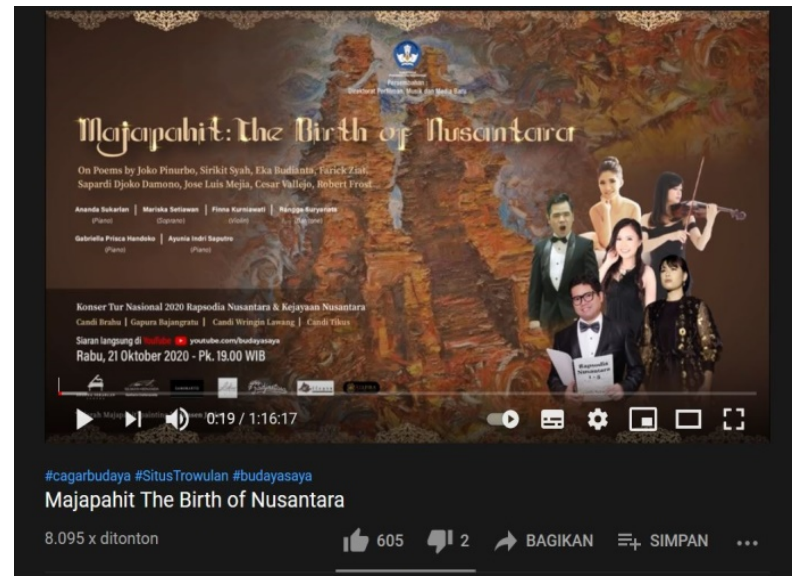

Sumber:https://www.youtube.com/watch?v=FARK3h6 yqa

Gambar 5 Tayangan di Kanal Youtube Budaya Saya yang Menampilkan Konser Rapsodia Nusantara I: Situs Trowulan bersama Ananda Sukarlan
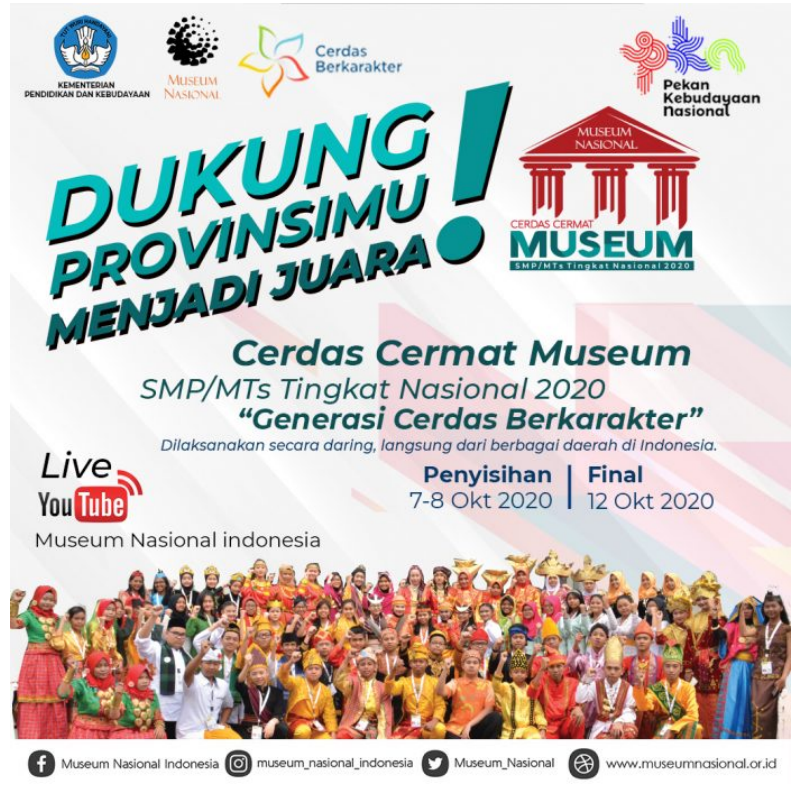

Sumber:https://www.museumnasional.or.id/cerdascermat-museum-2020-siap-digelar-3010

Gambar 6 Poster Cerdas Cermat yang diselenggarakan Museum Nasional Indonesia

BPCB Sulawesi Selatan pun tak tertinggal menunjukkan kreativitasnya dalam memberikan pelayanan kepada masyarakat. Kini siapa pun dapat melayangkan permohonan pelayanan publik secara online. Hanya dalam 3 tahapan, jika semuanya sudah dilengkapi, para pemohon tinggal menunggu balasan via ponsel.

Bagi pemohon yang ingin mengajukan permohonan terkait cagar budaya di wilayah kerja BPCB Sulawesi Selatan, kini tidak perlu repot untuk bersurat konvensional apalagi mendatangi kantor BPCB tersebut. Dengan mengisi formulir layanan, mengajukan surat permohonan layanan kepada Kepala BPCB Sulawesi Selatan serta mengunggah form tersebut, minimal 3 hari kerja sebelum kegiatan. Maka dalam jangka waktu kurang lebih 24 jam dari masuknya formulir tersebut, pemohon akan mendapat respons. Responsnya dapat berupa surat perizinan atau pun instruksi lanjutan lainnya dari bagian pelayanan publik.

Menurut petunjuk teknis yang dapat diunduh di laman BPCB Sulawesi Selatan, beberapa jenis layanan yang telah dikategorikan, yaitu:
a. Kunjungan Wisatawan Rombongan
b. Kunjungan Siswa
c. Kunjungan dengan Pemanduan
d. Kunjungan ke Situs Cagar Budaya yang Bukan Destinasi Wisata
e. Penelitian Mahasiswa
f. Penelitian oleh Peneliti Dalam Negeri
g. Penelitian oleh Peneliti Luar Negeri
h. Pengambilan Foto dan Video untuk Kepentingan Edukasi
i. Pengambilan Foto dan Video untuk Kepentingan Lainnya
j. Peminjaman Koleksi Buku Perpustakaan
k. Penyewaan Ruang Situs Cagar Budaya
I. Peminjaman Barang Milik Negara (BMN)
m. Peminjaman Mobil Bioskop Keliling.

\section{Peran Media Baru di Masa Pandemi}

Media baru telah menjadi media yang sangat populer digunakan di era teknologi saat ini. Media penyebaran informasi tidak terbatas dengan media cetak, namun juga mulai berkembang dengan produk-produk digital. Media baru memberikan pandangan dan suasana baru mengenai penyebaran informasi tentang cagar budaya karena lebih menarik dan interaktif. Media baru bisa menjadi jalan keluar di masa pandemi seperti saat ini karena mampu mengatasi keterbatasan yang ada. Seperti yang telah disebutkan sebelumnya, kegiatan yang berkaitan dengan penyebaran informasi tentang cagar budaya kemudian dilakukan secara virtual di dunia maya.

Tulisan ini akan melihat bagaimana peran media baru dalam upaya penyampaian informasi tentang cagar budaya, terutama kegiatan virtual yang dilaksanakan di masa pandemi seperti saat in. Berdasarkan survei yang telah dilakukan dengan menggunakan kuesioner yang memanfaatkan platform Google Form, sebanyak 106 responden 
telah menjawab sepuluh pertanyaan yang diajukan. Seperti yang dijelaskan dalam metode sebelumnya, statistik deskriptif hanya akan menjelaskan keadaan dari sebuah gejala yang telah direkam melalui alat ukur dan selanjutnya diolah sesuai dengan fungsi dan tujuan yang diinginkan. Hasil pengolahan tersebut kemudian dijelaskan dalam bentuk angkaangka, yang mempermudah siapa pun untuk mencerna maknanya (Siyoto dan Sodik 2015).

Kuesioner yang disebarkan diisi oleh 106 responden, yaitu 50 orang wanita dan 56 orang pria. Sebanyak 96 responden pernah mengikuti event/kegiatan bertema tentang cagar budaya secara daring selama masa pandemi Covid-19 dan sisanya belum pernah mengikuti (Gambar 7).

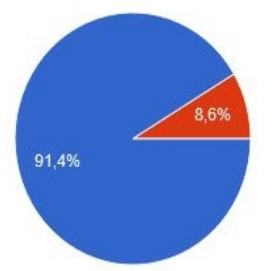

$$
\text { Yidak }
$$

Sumber: Dok. Penulis

Gambar 7 Diagram responden yang mengikuti kegiatan daring bertema cagar budaya

Lebih dari separuh jumlah responden yang mengikuti kegiatan bertema cagar budaya secara daring di masa pandemi ini didasari oleh kesadaran sendiri serta berkaitan dengan hubungan pekerjaan, sebanyak 35,9\% mengikuti kegiatan karena inisiatif mereka sendiri, sisanya hanya berkaitan dengan urusan pekerjaan, sekolah atau kuliah. Dari sekian banyak kegiatan yang digelar, kegiatan yang sering diikuti ialah Diskusi/Seminar/Lokakarya sebanyak $82,2 \%$ dari jumlah responden, disusul dengan pameran virtual, konser virtual, tur virtual, dan kegiatan lainnya (Gambar 8).

Sebanyak $75 \%$ responden menyatakan bahwa mereka lebih nyaman menggunakan laptop atau desktop untuk mengikuti kegiatan virtual dibandingkan dengan menggunakan handphone atau tablet. Layar yang lebih lebar mungkin menjadi alasan kenapa laptop atau desktop lebih dipilih dibanding dengan handphone atau tablet. Kegiatan daring bertemakan cagar budaya lebih sering mereka terima dari pesan singkat di media sosial yakni aplikasi WhatsApp dengan persentase $82,5 \%$, sisanya mereka mendapatkan informasi dari media sosial lain seperti Instagram, Facebook, dan website. Beberapa responden mendapatkan informasi tersebut dari surat undangan resmi yang dikirimkan di instansi pemerintah, sekolah, atau universitas sebanyak 48,5\% (Gambar 9).

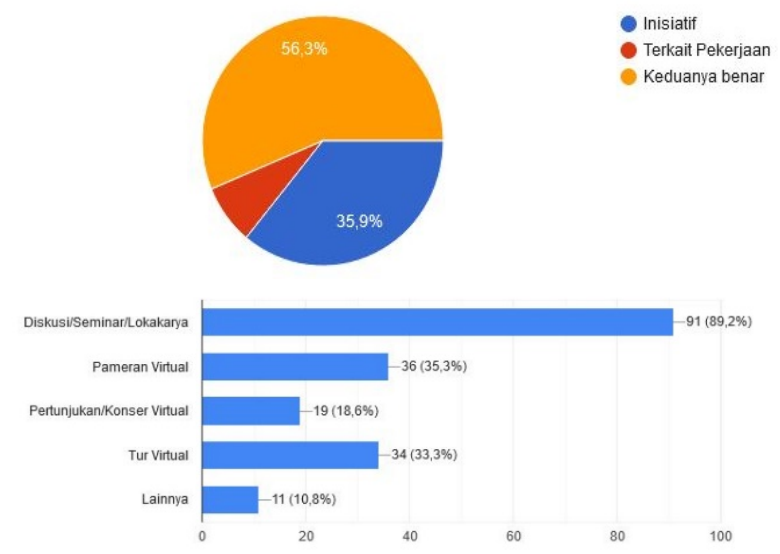

Sumber: Dok. Penulis

Gambar 8 Diagram dasar mengikuti kegiatan virtual dan kegiatan yang sering diikuti
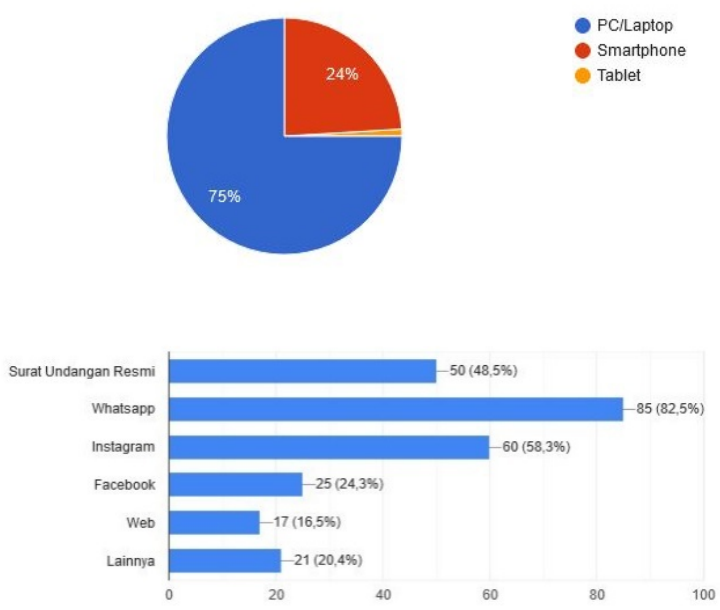

Sumber: Dok. Penulis

Gambar 9 Diagram gawai yang digunakan untuk mengikuti kegiatan virtual dan sumber informasi kegiatan virtual

Seringnya responden mengikuti kegiatan daring yang bertemakan cagar budaya juga bervariasi, sebagian besar responden $(68,9 \%)$ tidak menentu untuk mengikuti kegiatan daring yang diadakan. Hal tesebut dikarenakan adanya kesibukan yang bersamaan dengan jadwal kegiatan daring atau tema dari kegiatan daring tidak sesuai dengan minat dari responden. 26,2\% lainnya mengikuti kegiatan daring sebanyak 1-2 kali sebulan dan yang lainnya hingga 3-4 kali sebulan (Gambar 10). 


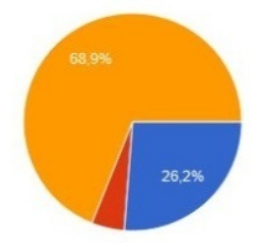

1-2 kali dalam sebula - 3-4 kali dalam sebula - tidak menentu

Sumber: Dok. Penulis

Gambar 10 Diagram seringnya mengikuti kegiatan virtual

Dari sekian banyak kegiatan daring yang bertujuan untuk menyampaikan informasi cagar budaya terdapat beragam kegiatan yang dianggap paling berkesan bagi responden, berikut kegiatan daring bertema cagar budaya yang menurut responden paling berkesan:

a. Kegiatan jalur rempah baik pameran dan karya inovatif yang diselenggarakan oleh instansi pemerintahan dan juga komunitas ataupun organisasi.

b. Kegiatan-kegiatan terkait dengan warisan budaya dunia, Ombilin Sawahlunto pun menarik minat responden.

c. Kegiatan yang berhubungan dengan praktik seperti konservasi, lokakarya GIS, dll.

d. Jelajah virtual situs di berbagai daerah di Indonesia hingga luar negeri.

e. Obrolan atau diskusi tentang heritage, baik dari stakeholders, institusi terkait arkeologi, maupun dari disiplin ilmu lain.

Selain ilmu pengetahuan dan pengalaman alasan menambah untuk menarik minat masyarakat mengikuti kegiatan daring yang bertemakan cagar budaya, beberapa penyelenggara sering memberikan hadiah atau souvenir kepada pesertanya. Menurut responden ada beberapa yang mereka harapkan setelah mengikuti kegiatan daring bertema cagar budaya seperti sertifikat, pulsa, relasi dan hadiah lainnya (Gambar 11).

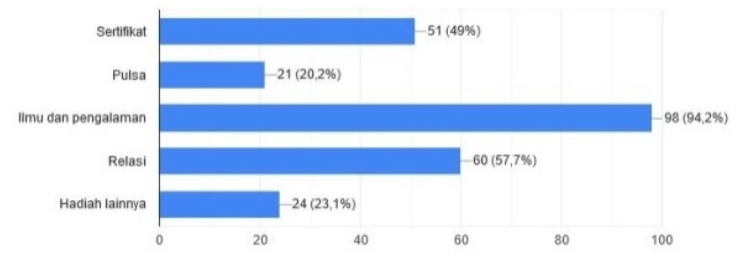

Sumber: Dok. Penulis

Gambar 11 Diagram hal yang diinginkan setelah mengikuti kegiatan virtual
Semenjak pandemi, hampir seluruh kegiatan dilangsungkan secara virtual. Pemanfaatan media baru sebagai media penyampaian informasi tentang cagar budaya dirasa paling tepat, namun bukan berarti tidak memiliki kendala. Beberapa responden mengeluh dengan gangguan jaringan internet ketika mengikuti kegiatan daring. Memang media baru sebagai penyebaran informasi sangat tergantung dengan jaringan internet. Belum meratanya jaringan internet di Indonesia menjadi masalah tersendiri dalam kelancaran kegiatan daring. Sering kali terjadi gangguan jaringan internet ketika kegiatan virtual berlangsung. Oleh karena itu, baik penyelenggara maupun peserta memastikan bahwa lokasi untuk mengikuti kegiatan virtual berada di daerah yang memiliki sinyal internet yang kuat, sehingga tidak terjadi gangguan ketika melakukan kegiatan virtual. Selain itu, sering terjadinya pemadaman listrik juga menjadi kendala. Salah satu cara untuk mengatasinya adalah dengan bersurat ke PLN, agar pada saat penyelenggaraan kegiatan virtual, tidak terjadi penurunan daya listrik ataupun pemadaman.

Menurut responden yang telah mengikuti kegiatan daring yang bertemakan cagar budaya, mereka menyatakan mendapatkan manfaat dari kegiatan yang mereka ikuti, antara lain:

a. Menambah wawasan dan pengetahuan

b. Menambah relasi

c. Media untuk menyebarkan ilmu

d. Menjalarkan semangat dan peduli terhadap cagar budaya nusantara.

\section{PENUTUP}

Berdasarkan apa yang telah diuraikan di atas mengenai permasalahan peran media baru dalam penyampaian informasi cagar budaya di masa pandemi, media baru memiliki peranan penting untuk menyebarkan informasi tentang cagar budaya, dari yang biasanya dilaksanakan tatap muka secara langsung dialihkan ke dunia maya. Media baru dapat menjembatani keterbatasan dalam mengumpulkan massa di suatu lokasi kemudian dipindahkan di ruang virtual, sehingga informasi penting yang berkaitan dengan cagar budaya tetap dapat disampaikan kepada masyarakat. Menggunakan jaringan internet dalam pelaksanaannya, penyebaran informasi cagar budaya menggunakan media baru juga dapat memberikan jangkauan lebih luas karena dapat 
diakses oleh masyarakat di Indonesia maupun di dunia.

Berdasarkan hasil kuesioner, banyak responden yang menyatakan bahwa kegiatan yang dilakukan secara virtual bermanfaat dalam memberikan pengalaman yang berbeda di tengah keterbatasan selama pandemi Covid-19. Selain itu, masyarakat juga dimudahkan dalam menerima informasi tentang cagar budaya melalui berbagai gawai elektronik yang dapat diakses dimana pun dan kapan pun tanpa harus mendatangi langsung lokasi kegiatan atau museum dan situs-situs bersejarah selama terhubung dengan internet.

Kegiatan virtual yang diselenggarakan baik oleh instansi pemerintah atau kelompok masyarakat yang peduli dengan pelestarian cagar budaya memang belum bervariasi, ketertarikan masyarakat dengan tema cagar budaya memang belum sebanyak dengan tema yang lainnya. Akan tetapi, media baru yang diyakini merupakan produk teknologi masa kini dapat menarik minat masyarakat dengan suguhan virtual yang lebih atraktif, komunikatif, dan interaktif.

Mengingat kegiatan virtual tampaknya masih menjadi primadona jika pandemi ini belum berakhir, maka penulis memiliki beberapa masukan terhadap penyelenggara, baik instansi maupun organisasi/komunitas. Pemilihan waktu kegiatan virtual harus benar-benar dipertimbangkan dengan matang, hal tersebut dikarenakan Indonesia terbagi dalam 3 wilayah yang waktunya berbeda, sehingga kadang peserta kerap melontarkan protes kalau waktu pelaksanaannya memberatkan.

Selain itu, durasi kegiatan juga harus dipertimbangkan dengan matang, karena banyak acara yang mundur dari jadwal yang telah ditentukan, sehingga mengganggu peserta yang memiliki kesibukan. Terakhir, penulis ingin mengingatkan etika sederhana yang kerap terlupakan saat mengikuti kegiatan daring, yaitu mengaktifkan kamera dan mematikan microphone jika bukan waktunya berbicara agar tidak mengganggu dan meminta izin kepada host jika ingin berbicara agar kegiatan berjalan lancar.

Mengingat kondisi dimana penyebaran Virus Corona masih meningkat, sehingga belum dapat dipastikan kapan pandemi Covid-19 akan berakhir maka tidak menutup kemungkinan bahwa penyampaian informasi cagar budaya secara virtual akan menjadi "New Normal" dalam kehidupan di masyarakat.

\section{DAFTAR PUSTAKA}

Amril, Fauzan. 2016. "Cyber Arkeologi dalam Komunikasi Arkeologi Kepada Publik Sebagai Sarana Pelestarian Cagar Budaya." Jurnal Konservasi Cagar Budaya Borobudur 10(2):39.

Mahmud, M. Irfan. 2012. "Arkeologi Untuk Semua: Bentuk dan Prospek Pemanfaatannya di Papua." Kalpataru 21(1):39-60.

Menteri Pendidikan dan Kebudayaan Republik Indonesia. 2020. "Surat Edaran Kemdikbud Nomor 4 Tahun 2020 Tentang Pelaksanaan Kebijakan Pendidikan dalam Masa Darurat Penyebaran Corona Virus Disease (Covid19)." 1-3.

Nugroho, Andy. 2020. "Teori New Media: Pegertian, Konsep dan Karakteristiknya." 9 Februari 2021. Retrieved (https://qwords.com/blog/teori -new-media).

Numatias. 2018. "Penguatan Teknologi Informasi Untuk Publikasi Cagar Budaya dan Permuseuman." Retrieved (http://kebudayaan. kemdikbud.go.id/bpcbsumbar/penguatan-teknologi-informasi-untuk-publikasi-cagar-budaya -dan-permuseuman/).

Prasasti, Shinta Dwi. 2019. "Pemanfaatan Media Sosial Sebagai Sarana Publikasi Pelestarian Cagar Budaya dalam Perspektif Arkeologi Publik." Jurnal Widya Prabha (8):68-76.

Presiden Republik Indonesia. 2010. UndangUndang Nomor 11 Tahun 2010 Tentang Cagar Budaya. Indonesia.

Presiden Republik Indonesia. 2020. Peraturan Pemerintah (PP) Tentang Pembatasan Sosial Berskala Besar dalam Rangka Percepatan Penanganan Corona Virus Disease 2019 (COVID-19). Indonesia.

Revianur, Aditya. 2020. "Digitalisasi Cagar Budaya di Indonesia: Sudut Pandang Baru Pelestarian Cagar Budaya Masa Hindu-Budha di Kabupaten Semarang dalam Bakti Budaya." Jurnal Pengabdian Kepada Masyarakat 3(1):90-101. 
Arkeologi Publik: Peran Media Baru dalam Penyampaian Informasi Cagar Budaya di Masa Pandemi- Komang Ayu Suwindiatrini dan Helmi Yanuar Dwi Prasetyo (61-72)

Doi: 10.24832/ke.v7i1.85

Sekretariat Direktorat Jenderal, Direktorat Jenderal Kebudayaan Republik Indonesia. 2016. "Tentang Direktorat Jenderal Kebudayaan." 8 Februari 2021. Retrieved (https://kebudayaan. kemdikbud.go.id/tentang-kami/).

Sektiadi. 2008. "Museum dan Dunia Maya." Dalam Proceeding Pertemuan IImiah Arkeologi XI Solo. Jakarta: Ikatan Ahli Arkeologi Indonesia.
Siyoto, Sindu, dan Ali Sodik. 2015. Dasar Metodologi Penelitian. Yogyakarta: Literasi Media Publishing.

Widodo, Suko. 2012. "Mengkomunikasikan Makna Arkologi Bagi Publik dalam Konteks Kekinian." HIm. 33-38 dalam Arkeologi untuk Publik. Jakarta: Ikatan Ahli Arkeologi Indonesia. 